\title{
Effects of Integrated Use of Calcite and Inorganic Fertilizer on Soil Physicochemical Properties and Maize (Zea mays I.) Yield and, Economic Feasibility on the Nitisols of Northwestern Ethiopia
}

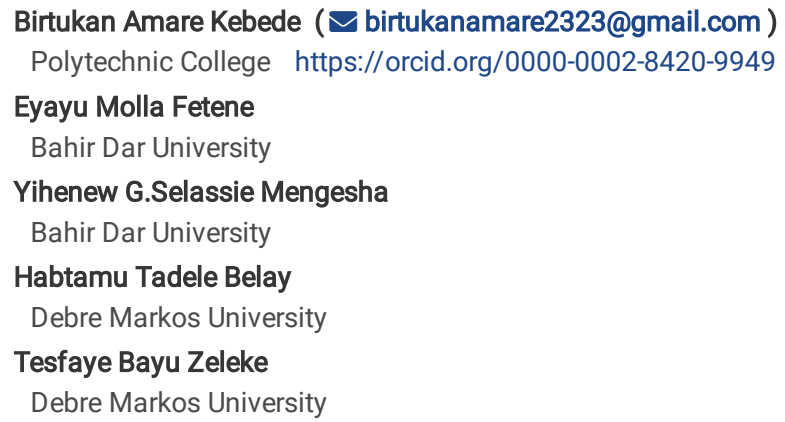




\section{Abstract}

Background: Understanding the soil reaction $(\mathrm{pH})$ is relevant for improving crop productivity. Soil acidity is one of the restraining factors to crop production in the highlands of Ethiopia. This study was carried out on the nitisols of Burie District to examine the effect of integrated use of Calcite and Nitrogen fertilizer on soil physico-chemical properties. Treatments were two levels of lime $\left(0\right.$ and $\left.0.50 \mathrm{t} \mathrm{ha}^{-1}\right)$ and five-level of nitrogen $\left(0,100,200,300\right.$, and $\left.400 \mathrm{~kg}^{-1}\right)$. The experiment was laid out in randomized complete block design (RCBD) with ten treatments replicated three times. Before and after harvest, both disturbed and undisturbed soil samples were collected. Analysis of variance (ANOVA) and bivariate correlations was employed using SAS statistical package program version 9.0. After harvesting thirty soil samples were collected from each treatment and then ten composite soil samples within a block were arranged for laboratory analysis.

Result: The result indicated that among the soil properties before planting the crop soil bulk density (BD), pH, organic carbon (OC), total nitrogen (TN), available P and CEC were $1.43 \mathrm{~g} \mathrm{~cm}^{-3}, 5.2$ (strongly acidic), $1.32 \%$ (very low), $0.12 \%$ (low), $8.86 \mathrm{mg} \mathrm{kg}^{-1}$ (very low), and $19.57 \mathrm{cmol}_{\mathrm{C}} \mathrm{kg}^{-1}$ (medium), respectively. After harvesting, most of the surface physico-chemical properties except bulk density increased. The lowest soil BD was $1.21 \mathrm{~g} \mathrm{~m}^{-3} \mathrm{from}$ plots treated with 0.5 t ha ${ }^{-1}$ lime and $400 \mathrm{~kg} \mathrm{ha}^{-1}$ urea. The maximum soil pH (6.85) was obtained from plots treated with $400 \mathrm{~kg} \mathrm{ha}^{-1} \mathrm{~N}$ and $0.5 \mathrm{t}$ ha ${ }^{-1}$ lime. The maximum soil CEC $\left(35.38\left(\mathrm{cmol}_{\mathrm{C}} \mathrm{kg}^{-1}\right)\right.$ was obtained from plots treated with $400 \mathrm{~kg} \mathrm{ha}^{-1} \mathrm{~N}$ and $0.5 \mathrm{t} \mathrm{ha}^{-1}$ lime. Level of lime, nitrogen fertilizer and interaction effects of lime and nitrogen fertilizer $\left(L^{\star} N\right)$ significantly affected maize yield $(p<0.001)$. Yield of maize have positive correlations with most soil physico-chemical properties but negative with BD ( $r=-0.543)$. The adjusted yield and net benefit was $6,410.20 \mathrm{~kg} \mathrm{ha}^{-1}$ and $58,891.47$ Ethiopian Birr (ETB), respectively.

Conclusion: Inherent physicochemical properties of the soil is changed either by sole or combined use of lime and $\mathrm{N}$ fertilizer. Soils tilled with $0.5 \mathrm{t}$ ha ${ }^{-1}$ lime and $138 \mathrm{~kg} \mathrm{ha}^{-1}$ nitrogen was found in maximum net benefit. Residual long-term effects should be researched. Thus, liming should be given emphasis in acidic soil amelioration. Moreover, the government may facilitate the supply of calcite $\left(\mathrm{CaCO}_{3}\right)$ and urea fertilizer to the farmers.

\section{Background}

Soil fertility management for food and livelihood security is a major concern in the face of persistent poverty and widespread environmental degradation in Sub-Saharan Africa (SSA) including Ethiopia (Bello et al., 2010). About $97 \%$ of the agricultural lands in SSA are under a rain-fed system Bello et al. (2010)which remains the dominant source of food production shortly. Besides, Worku et al. (2012) reported that nutrient depletion is the chief biophysical factor limiting small-scale production in Africa.

In Ethiopia, soil degradation and nutrient depletion have gradually increased and become serious threats to agricultural productivity (Kebede and Yamoah 2009). Soil acidity is one of the limiting factors to acid-sensitive crops in the Northwestern highlands of Ethiopia (Kebede and Yamoah 2009). Its effects on crop growth are those related to the deficiency of major nutrients and the toxicity of aluminum ( $\mathrm{Al})$, manganese $(\mathrm{Mn})$, and hydrogen $(\mathrm{H})$ to plants $(\mathrm{Mesfin}$ 2009). To secure sustainable crop production and reasonable yield, acidic soils have to be corrected by the addition of agricultural lime to a pH range that is suitable for better yield of crop production and to improve soil physicochemical properties (Mesfin 2009). Liming materials raise the soil pH and increase the productivity of crops. Agricultural lime is a material containing calcium (Ca) and/or magnesium (Mg) compounds capable of neutralizing soil acidity (Moreira and Fageria 2010). Short-term effects of lime, i.e., less than one year are likely to be the result of physicochemical effects. On highly-weathered acidic tropical soils, where relatively low lime rates are applied to neutralize exchangeable Al (usually to raise $\mathrm{pH}-\mathrm{H}_{2} \mathrm{O}$ to $5.3-5.6$ ), precipitation of exchangeable $\mathrm{Al}$ as hydroxyl-Al species will be the main factor for improving soil structural condition (Haynes and Naidu 1998). A liming material with a higher Calcium Carbonate Equivalence (CCE) value will have greater effectiveness than one with a lower CCE value. Impurities, such as clay and organic matter that naturally occur in liming materials create variations in CCE among different liming materials (Moreira and Fageria 2010). The common liming materials used to ameliorate acidity are calcium oxide $(\mathrm{CaO})$ and calcium carbonate $\left(\mathrm{CaCO}_{3}\right)$ in powdery formulations $(0$ pala et al., 2018). Among these, $\mathrm{CaCO}$ is available in Ethiopia and recommended to raise the soil $\mathrm{pH}$. The level of acidity in the study area was strongly acidic (5.20) that needs liming materials such as $\mathrm{CaCO}_{3}$. Therefore, this study was initiated to to evaluate the effects of short-term combined use of lime and $\mathrm{N}$ fertilizer on soil physico-chemical properties on the nitisols of Bure District Northwest Ethiopia.

\section{Materials And Methods}

\section{Research site location and soil}

The experiment was conducted in Burie district, West Gojjam Zone of Amhara National Regional State (ANRS) during the 2018/2019 main cropping season. The study site is located between latitude of $10^{\circ} 43^{\prime} 0^{\prime \prime}$ to $10^{\circ} 47^{\prime} 0^{\prime \prime}$ North and longitude of $37^{\circ} 3^{\prime} 0^{\prime \prime}$ to $37^{\circ} 6^{\prime} 0^{\prime \prime}$ East. It is located in the northwestern part of Ethiopia at a distance of $411 \mathrm{~km}$ from Addis Ababa and $148 \mathrm{~km}$ southwest of Bahir Dar city. The altitude of the Burie district ranges from 2087 to 2,637 m.a.s.I. The soil of the area is characteristically humic Nitisols. In general, soils of the area are well-drained, clay in texture, and strongly acidic Nitisols in soil reaction. The district has a total of 29,629 ha agricultural land from this $42.8 \%$ is covered by maize crop in the 2018/2019 crop production year. The mean yield of maize from all varieties was 5.55 tha $^{-1}$ which is low as compared with the production potential of the area. The experimental site was covered by wheat crop during the past cropping seasons. Local agricultural office recommended N and NPS fertilizers in the study area are $200 \mathrm{~kg}^{-1} \mathrm{~N}^{-1} \mathrm{and} 200 \mathrm{~kg}$ ha-1 NPS, respectively.

According to the Amhara Meteorological Agency report (2020), the mean annual rainfall of the District was $1375.8 \mathrm{~mm}$ and the mean minimum, mean

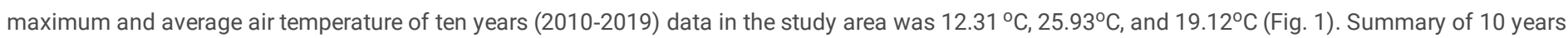
(2010-2019) mean annual rainfall and temperature data of study area is presented. 


\section{Plant, fertilizer and lime}

The maize variety H-661 (Bako Hybrid-661) which is adapted to the agro-ecology and registered at the national level was collected from Amhara Seed Enterprise and used as a test crop.

As a feretilizer urea $(46 \% \mathrm{~N})$ was applied at five different rates $\left(0,100,200,300\right.$, and $\left.400 \mathrm{~kg} \mathrm{ha}^{-1}\right)$ and was applied in one dose at knee height sage. This fertilizer was applied by banding at a distance 2 to $3 \mathrm{~cm}$ away from the plant and at $20 \mathrm{~cm}$ depth and covered immediately with soil.The recommended rate of NPS $\left(19 \% \mathrm{~N}, 38 \% \mathrm{P}_{2} \mathrm{O}_{5}\right.$, and $\left.7 \% \mathrm{~S}\right)$ fertilizer was uniformly applied to all plots at the time of planting.

Liming material in the form of calcium carbonate $\left(\mathrm{CaCO}_{3}\right)$ passed a 100-mesh was applied. According to Burie district Agricultural Office Manual (2019), there are two ways of lime application. First, during seed sowing (i.e row application) if the lime is a powder, and the secondis broadcasting application for granular type of lime. First, during seed sowing one fourth $\left(20 \mathrm{t} \mathrm{ha}^{-1}\right)$ of the recommended rate of broadcasting (i.e $0.5 \mathrm{t} \mathrm{ha}{ }^{-1}$ lime) was applied. Broadcasting application is recommended to apply one or two months before seed sowing (BDAO, 2019). Lime was added as the district agricultural office manual, based on the soil pH of the experimental site. According to $\mathrm{BDAO}(2019)$ unpublished mannual, if the $\mathrm{pH}\left(\mathrm{H}_{2} \mathrm{O}\right)$ value of the soil is between 5.14 to 5.32 , the recommended lime rate for broadcasting application method is $20 \mathrm{t} \mathrm{ha}^{-1}$. For row application method, $0.5 \mathrm{t}^{-1}$ of the recommended rate for broadcasting method was used. Since the soil pH of experimental site was 5.20 , the amount of lime rate added during maize sowing was $0.5 \mathrm{t} \mathrm{ha} \mathrm{T}^{-1}$.

\section{Evaluation of changes in soil properties}

Before sowing the seed, ten disturbed soil samples were taken at a depth of 0 to $20 \mathrm{~cm}$ at different points by vertical insertion of a shovel and mixed to get one composite sample. Similarly, ten representative undisturbed samples were taken for bulk density determination using core sampler. Likewise, 30 disturbed soil sample were collected from each plot within a block and reduced into ten composite sample for soil chemical property analysis. On the other hand, after harvest, 30 undisturbed samples were also collected from each plot within a block for BD determination. The composite surface soil and individual soil samples from each plot after treatment were properly labeled and the lables were placed both inside and outside the plastic bags and were transported to the soil laboratory of Amhara Design and Supervision Works Enterprise.

\section{Analysis of soil physical properties}

Soil bulk density was measured from undisturbed soil samples collected using a core sampler (which was weighed at field moisture) after drying the preweighed soil core samples to constant weight in an oven at $105^{\circ} \mathrm{C}$ as per the procedures described by (Blake 1965). Then soil bulk density was calculated by dividing the masses of the oven-dried soils by their respective total volume of the core sampler.

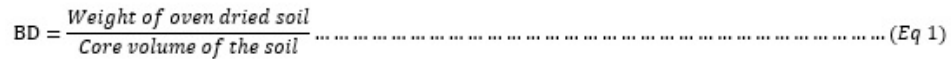

Where,

BD: bulk density $\left(\mathrm{g} \mathrm{cm}^{-3}\right)$, weight of oven dried soil (gram) and core volume of the soil $\left(\mathrm{cm}^{-3}\right)$

\section{Analysis of soil chemical properties}

The composite soil samples were air-dried, mixed well, and passed through a $2 \mathrm{~mm}$ sieve for the analysis of selected chemical properties. Soil pH was measured using a pH meter in a 1:2.5 soil: water ratio suspension as outlined by Van (1993). Soil OC was determined by the Walkley and Black wet digestion method (Walkley and Black 1934), and the soil OM was calculated by multiplying the percent organic carbon by a factor of 1.724 . Total $\mathrm{N}$ was determined using the micro-Kjeldahl digestion, distillation, and titration procedure as described by Bremner and Mulvaney (1982). Available P was determined using the standard Olsen extraction method (Olsen 1954). CEC was measured by ammonium acetate extraction method (Chapman 1665).

\section{Fertilizer application and field activities}

The experimental plot plowed three times; the first plowing was done on the first of April with a disc plough. The second and final plowing was conducted by oxen-driven local plow called "Maresha" at first and last dates of May. Spacing of maize plants was $75 \mathrm{~cm}$ between rows and $25 \mathrm{~cm}$ between plants. The experimental field was hand weeded twice at 25 and 45 days after planting. A late-emerging weeds were removed by hoeing to avoid mixup between the $\mathrm{N}$ applied and non-applied treatments. All other agronomic practices such as fertilization, hoeing, disease, insects, and weeds management were as per the recommendation. Maize plants in the central net plot area were harvested leaving one boarder row from each side of each plot.

\section{Data Analysis}

Analysis of variance (ANOVA) was carried out using SAS statistical package program version 9.0 (SAS, 2004). Duncan's Test was used to assess yield differences among treatment means where significant differences were obtained by the analysis of variance. Soil physico-chemical properties bivariate correlations on yield of maize was also carried out. Finally, soil physico-chemical properties comparison with critical values was done.

\section{Results And Discussion}

Soil physicochemical properties before and after an amendment are presented as shown in Table 1 and Figure 2. 
Table 1 Plough depth soil physicochemical property status before soil amendment

\begin{tabular}{lccc}
\hline Soil properties & Values & Critical values & Reference \\
\hline Sand (\%) & 22.00 & -- & \\
Silt $(\%)$ & 31.00 & --- & \\
Clay (\%) & 47.00 & --- & \\
Classes & Clay &.-- & (Karltun et al., 2014) \\
BD g cm & (Karltun et al., 2014) \\
pH $\left(\mathrm{H}_{2} \mathrm{O}\right)$ & 1.42 & 1.20 & (Karltun et al., 2014) \\
TN \% & 5.20 & 7.30 & (Yihenew G. Selassie 2014) \\
Available P (mg kg-1) & 0.12 & 0.20 & (Landon 1991) \\
Organic carbon (\%) & 1.32 & 11.10 & (Landon 1991) \\
CEC $\left(\mathrm{cmol}_{\left.\mathrm{C} \mathrm{kg}^{-1}\right)}\right.$ & 19.57 & 15.00 & \\
\hline
\end{tabular}

As shown in Table 2 lime and $\mathrm{N}$ fertilizer interaction had a significant $(P \leq 0.01)$ effect on grain yield of maize Therefore; application of $0.50 \mathrm{t}$ ha ${ }^{-1}$ lime with $300 \mathrm{~kg} \mathrm{ha}^{-1}$ nitrogen fertilizer is economical with marginal rate of return value $805.24 \%$. Soil physico-chemical properties have positive correlations on yield of maize except BD (Table 3).

Table 2 Interaction Effect of lime and Nitrogen fertilizer on soil physico-chemical properties and maize yield after amendment

\begin{tabular}{|c|c|c|c|c|c|c|c|c|c|}
\hline & & & & & \multicolumn{4}{|c|}{ Soil physico-chemical properties } & Grain yield \\
\hline Treatment & $\begin{array}{c}\mathrm{BD} \\
\left(\mathrm{g} \mathrm{cm}^{-3}\right)\end{array}$ & $\begin{array}{c}\mathrm{pH} \\
\left(\mathrm{H}_{2} \mathrm{O}\right)\end{array}$ & $\begin{array}{l}\text { SOC } \\
(\%)\end{array}$ & $\begin{array}{l}\mathrm{OM} \\
(\%)\end{array}$ & $\begin{array}{l}\text { TN } \\
(\%)\end{array}$ & $\mathrm{C}: \mathrm{N}$ & $\begin{array}{c}\text { Available } \\
\left(\mathrm{mg} \mathrm{kg}^{-1}\right)\end{array}$ & $\begin{array}{c}\text { CEC } \\
\left(\mathrm{cmol}_{\mathrm{C}} \mathrm{kg}^{-1}\right)\end{array}$ & $\left(\mathrm{kg} \mathrm{ha}^{-1}\right)$ \\
\hline Intial values & 1.42 & 5.20 & 1.32 & 2.27 & 0.12 & 11.00 & 8.86 & 19.57 & ---- \\
\hline $\mathrm{T} 1$ & 1.40 & 5.56 & 1.33 & 2.29 & 0.124 & 10.75 & 12.24 & 22.17 & $3,442.47^{j}$ \\
\hline $\mathrm{T} 2$ & 1.39 & 5.51 & 1.36 & 2.34 & 0.126 & 10.03 & 15.28 & 22.19 & $5,294.73^{h}$ \\
\hline T3 & 1.37 & 5.49 & 1.39 & 2.39 & 0.129 & 10.78 & 16.30 & 22.64 & $5,766.53^{g}$ \\
\hline $\mathrm{T} 4$ & 1.35 & 5.21 & 1.59 & 2.73 & 0.147 & 10.82 & 17.78 & 22.68 & $6,116.14^{\mathrm{e}}$ \\
\hline T5 & 1.32 & 4.98 & 1.86 & 3.18 & 0.179 & 10.39 & 26.04 & 23.36 & $6,892.8^{c}$ \\
\hline T6 & 1.26 & 5.85 & 1.29 & 2.22 & 0.120 & 10.75 & 18.60 & 27.25 & $3,758.42^{\mathrm{i}}$ \\
\hline T7 & 1.24 & 6.59 & 2.23 & 3.84 & 0.205 & 10.87 & 22.84 & 31.43 & $6,062 \cdot 35^{f}$ \\
\hline T8 & 1.23 & 6.71 & 2.45 & 4.21 & 0.226 & 10.84 & 24.73 & 33.21 & $6,516.03^{d}$ \\
\hline T9 & 1.22 & 6.76 & 2.48 & 4.28 & 0.228 & 10.88 & 25.62 & 34.46 & $7,122.44^{b}$ \\
\hline T10 & 1.21 & 6.85 & 2.51 & 4.33 & 0.231 & 10.86 & 30.43 & 35.38 & $7,669.88^{a}$ \\
\hline Mean & 1.23 & 5.95 & 1.85 & 3.18 & 0.17 & 10.69 & 20.98 & 27.47 & --- \\
\hline LSD (0.05) & & & & & & & & & 49.87 \\
\hline$S E \pm$ & & & & & & & & & 59.74 \\
\hline CV & & & & & & & & & 0.50 \\
\hline$p$ & & & & & & & & & $* *$ \\
\hline
\end{tabular}

T1-control (200 kg ha-1 NPS); T2- NPS (200 kg ha-1) + Urea (100 kg ha-1); T3- NPS (200 kg ha-1) + Urea (200 kg ha-1);

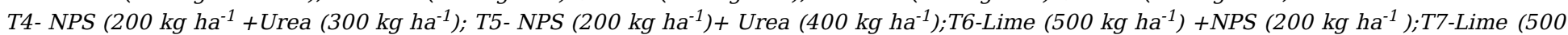

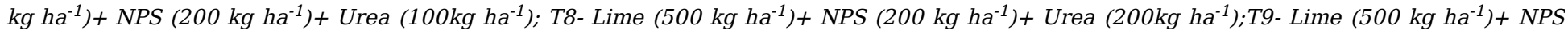
$\left(200 \mathrm{~kg} \mathrm{ha}^{-1}\right)+$ Urea $\left(300 \mathrm{~kg} \mathrm{ha}^{-1}\right) ;$ T10-Lime $\left(500 \mathrm{~kg} \mathrm{ha}^{-1}\right)+N P S\left(200 \mathrm{~kg} \mathrm{ha}^{-1}\right)+$ Urea $\left(400 \mathrm{~kg} \mathrm{ha}^{-1}\right)$, GY=grain yield, LSD=Least significance difference, $S E \pm=$ Standard error; $C V=$ Coefficient of Variation, $p=$ probability level; $* *=$ significantly different at $p<0.05$.

Means followed by the same letters in a column are not significantly different at $p<0.05$

As shown in Table 3 the comparison of the correlation coefficients between siol physico-chemical properties and yield showed that available $\mathrm{P}$ gave a higher correlation coefficient $\left(r=0.838^{\star *}\right)$ to the number of other soil properties followed by the soil total $N\left(r=0.803^{\star *}\right)$.

Table 3 Soil physico-chemical properties bivariate correlations on maize yield

\begin{tabular}{|c|c|c|c|c|c|c|c|c|}
\hline & $\begin{array}{c}\mathrm{BD} \\
\left(\mathrm{g} \mathrm{cm}^{-3}\right)\end{array}$ & $\begin{array}{c}\mathrm{pH} \\
\left(\mathrm{H}_{2} \mathrm{O}\right)\end{array}$ & $\begin{array}{c}\text { SOC } \\
(\%)\end{array}$ & $\begin{array}{l}\mathrm{OM} \\
(\%)\end{array}$ & $\begin{array}{l}\mathrm{TN} \\
(\%)\end{array}$ & $\begin{array}{c}\text { Available P } \\
\left(\mathrm{mg} \mathrm{kg}^{-1}\right)\end{array}$ & $\begin{array}{c}\mathrm{CEC} \\
\left(\mathrm{cmol}_{\mathrm{C}} \mathrm{kg}^{-1}\right)\end{array}$ & $\begin{array}{c}\text { Yield } \\
\left(\mathrm{kg} \mathrm{ha}^{-1}\right)\end{array}$ \\
\hline $\mathrm{BD}$ & 1 & $-0.840^{* *}$ & $-0.836^{* *}$ & $-0.837^{* *}$ & $-0.830^{* *}$ & $-0.840^{* *}$ & $-0.950^{* *}$ & $-0.543^{\mathrm{ns}}$ \\
\hline $\mathrm{pH}$ & & 1 & $0.806^{* *}$ & $0.810^{* *}$ & $0.782^{* *}$ & $0.599^{\text {ns }}$ & $0.954^{* *}$ & $0.403^{\mathrm{ns}}$ \\
\hline $\mathrm{OC}$ & & & 1 & $1.000^{* *}$ & $0.999^{* *}$ & $0.880^{* *}$ & $0.899^{* *}$ & $0.799^{* *}$ \\
\hline $\mathrm{OM}$ & & & & 1 & $0.998^{* *}$ & $0.878^{* *}$ & $0.902^{* *}$ & $0.797^{* *}$ \\
\hline $\mathrm{TN}$ & & & & & 1 & $0.893^{* *}$ & $0.885^{* *}$ & $0.809^{* *}$ \\
\hline $\mathrm{P}$ & & & & & & 1 & $0.794^{* *}$ & $0.838^{* *}$ \\
\hline CEC & & & & & & & 1 & $0.564^{\mathrm{ns}}$ \\
\hline Yield & & & & & & & & 1 \\
\hline
\end{tabular}

**. Correlation is significant, ${ }^{\text {ns }}$ non-significant ${ }^{\text {at }} 0.01$ level (2-tailed).

As shown in Fig 2 bulk density, soil pH, TN, available P, OC and OM are below the critical values of the soil for crop production. But cation exchange capacity of the study area soil is optimum because of the soil textural class. Thus application of lime and $\mathrm{N}$ fertilizer improves soil chemical properties through improving organic matter and total nitrogen in the soil. 
Table 4 Marginal rate of return analysis of Maize

\begin{tabular}{|c|c|c|c|c|c|c|}
\hline Treatments & $\begin{array}{c}\text { Grain Yield } \\
\left(\mathrm{kg} \mathrm{ha}^{-1}\right)\end{array}$ & Adjusted yield $(-10 \%)\left(\mathrm{kg} \mathrm{ha}^{-1}\right)$ & Gross return (ETB ha-1) & TVC(ETB ha-1) & $\begin{array}{c}\text { Net benefit } \\
\left(\text { ETB ha }^{-1}\right)\end{array}$ & $\begin{array}{r}\text { MRR } \\
(\%)\end{array}$ \\
\hline T1 & 3530.15 & 3177.14 & 31771.35 & 5928.92 & 25842.43 & --- \\
\hline T6 & 3671.75 & 3304.60 & 33045.75 & 6689.27 & 26356.49 & 67.60 \\
\hline T2 & 5294.73 & 4765.26 & 47652.57 & 8599.70 & 39052.889 & 664.50 \\
\hline T7 & 6062.35 & 5456.12 & 54561.15 & 9598.29 & 44962.87 & 591.80 \\
\hline T3 & 5766.53 & 5189.88 & 51898.77 & 9899.13 & $41999.64 \mathrm{D}$ & --- \\
\hline T8 & 6516.03 & 5864.44 & 58644.27 & 10943.23 & 47701.04 & 203.59 \\
\hline $\mathrm{T} 4$ & 6116.14 & 5504.52 & 55045.26 & 11281.57 & $43763.69 \mathrm{D}$ & --- \\
\hline T9 & 7122.44 & 6410.20 & 64101.96 & 12332.93 & 58891.47 & 805.24 \\
\hline T5 & 6892.80 & 6203.52 & 62035.20 & 12630.82 & $51769.03 \mathrm{D}$ & --- \\
\hline T10 & 7669.88 & 6902.90 & 69028.92 & 13667.99 & $55360.93 \mathrm{D}$ & --- \\
\hline
\end{tabular}

$D=$ dominated treatment

\section{Discussion}

The results of soil analysis before application of calcite and $\mathrm{N}$ fertilizer for maize crop is presented in Table 1. Before harvesting, BD of the soil was $1.42 \mathrm{gcm}$ ${ }^{3}$ with clay texture (Table 1). The high BD value might be due to compactness of the soil and lower OM content that resulted from continuous cultivation and removal of plant roots and residues. Thus, as per the critical value rated by Karltun et al. (2014), the soil of the study area has a higher BD. This is supported by Karltun et al.(2014) reported an increase in bulk density due to compaction and decreasing soil pore space in Ethiopia. Bulk densities of soils are inversely related to the amount of pore space and soil OM (Gupta 2000; Brady and Weil 2008). Any factor that influences soil pore space will also affect the bulk density. For instance, exhaustive cultivation increases bulk density resulting in a decrease of total porosity (Brady and Weil 2008).

The soil reaction $\left(\mathrm{pH}-\mathrm{H}_{2} \mathrm{O}\right)$ was strongly acidic with a value of 5.2 (Table 1$)$. According to Assefa (2009), pH less than 4.5 is classified as strongly acidic, $4.5-$ 5.5: highly acidic, 5.6-6.5: moderately acidic, 6.6-7.3: neutral, 7.4-8.4: moderately alkaline, >8.5: strongly alkaline. Therefore, soils of the study area are strongly acidic.

The soil OC contents were $1.32 \%$ (Table 1 ), which is rated as very low $(<1.7 \%)$ to low $(2-4 \%)$ as per the rating of soil test values interpretation by Landon (1991). Based on this result, soil OC of the study area rated as very low compared to the critical value (3\%). This might be due to the removal of plant tissues and root residue from the soil. For a soil to be productive, it needs to have OC content in the range of 1.8-3\% so as to achieve good soil structural conditions and structural stability (Abera and Wolde-Meskel 2013).

The content of Total Nitrogen (TN) also followed the trend of soil OC which had a value of $0.12 \%$ (Table 1). According to Assefa (2009), TN rated as very low $(<0.10 \%)$, low $(0.1-0.15 \%)$ and optimum (0.15-0.30\%). Based on these ratings, the study area had lower TN content. These minimum soil OC and TN values are expected in the maize-growing fields of the study area where there is complete removal of biomass from the crop field, lower application rate of fertilizers, and continuous cultivation that favors rapid rate of mineralization (Abera and Wolde-Meskel 2013).

Available $\mathrm{P}$ before the application of lime and urea fertilizer was very low ( $\left.8.86 \mathrm{mg} \mathrm{kg}^{-1}\right)$ in acidic Nitisols of the study area (Table 1). The value is below the critical level of available P on Nitisols of Northwestern Ethiopia for maize is $11.10 \mathrm{mg} \mathrm{kg}^{-1}$ in Alfisols as suggested by Yihenew G. Selassie (2016). This might be attributed to $\mathrm{P}$ fixation due to the acidic nature of the soil and is not readily available to plant uptake. The low application rates of P-containing fertilizers, continuous crop uptake, losses due to erosion and fixation by acidic soils in this maize-growing field of the study area might be linked to the inadequate $P$ levels recorded in the studied soils.

The CEC value of Nitisols of the study area was $19.57 \mathrm{cmolc} \mathrm{kg}^{-1}$ (Table 1), which is rated as a medium as per the ratings of (Karltun et al., 2014). According to this author, soils having CEC of $>40,25-40,15-25,5-15,<5 \mathrm{cmol}_{\mathrm{C}} \mathrm{kg}^{-1}$ categorized as very high, high, medium, low, and very low, respectively (Karltun et al., 2014). The level of CEC could be associated with the texture of the soil which is clay. Clay soils have more cations as they have the characteristics of increasing negative surface charges of soil.

\section{Effect of Calcite and Nitrogen Fertilizer on Soil Physicochemical Properties}

\section{Change in soil bulk density}

Due to the application of lime, bulk density was declined in all plots (Table 2). This could be aggregation of soil and improve soil crusting. However, the highest reduction (from 1.42 to $1.21 \mathrm{~g} \mathrm{~cm}^{-3}$ ) was recorded in plots treated with $0.50 \mathrm{t} \mathrm{ha}^{-1}$ lime with $400 \mathrm{~kg} \mathrm{ha}^{-1}$ urea. This might be due to the increasing effect of soil organic matter (SOM) after harvest that makes the soil less compact and reduces the BD. Similarly, Tesfaye (2017) found a decrease in soil BD as a result of integrated use of soil fertilizers in maize cultivated land at Yilmana Densa district northwestern Ethiopia. The result was also similar to Muhammad (2011) who found lower bulk density as a result of nutrient and crop management on the crops sugarcane, maize, sorghum, and cotton residues at Gatton, Southern Queensland Australia. However, as Bayu (2006) reported, the application of inorganic fertilizers alone had no significant effect on the bulk density of the soil. Similarly, Shirani et al. (2002) reported a significant decrease in soil bulk density just after harvesting a maize field supplied with integrated use of lime and inorganic fertilizers. Likewise, Onwonga et al. (2010) reported the positive effect of integrated use of lime, manure, and mineral fertilizers on soil physical and chemical properties on maize production at the Kenya Agricultural Research Institute field station.

\section{Change $\mathrm{pH}$ of soil}


Soil pH was affected by integrated nutrient management that increased with the application of lime and $\mathrm{N}$ fertilizer (Table 3). In the sole application of urea fertilizer, the highest (5.51) and lowest pH (4.98) were recorded in plots treated with 100 and $400 \mathrm{~kg} \mathrm{ha}^{-1}$ urea, respectively (Table 2). Though, nitrogen fertilizers increase crop yield, at the same time they also increase soil acidity. This is because during ammonium is converted to nitrate, and released hydrogen ion which is one of the contributing factors leading to acidification. Hence, the application of $\mathrm{N}$ fertilizers containing $\mathrm{NH}_{4}{ }^{+}$or even adding large quantities of organic matter to the soil can ultimately increase soil acidity and lower the pH Guo (2010). Similarly, Opala et al. (2018) found that the pH of soil treated with inorganic urea fertilizer was 5.21 as compared to the control pH (4.92) on maize cultivated acidic soils of Western Kenya. Conversely, the sole application of lime effectively increased the soil pH from 5.2 to 5.85 (Table 2). This rise in $\mathrm{pH}$ of the soil is associated with the presence of basic cations (Ca ${ }^{2+}$ ) and anions $\left(\mathrm{CO}_{3}{ }^{2-}\right)$ in lime that can exchange $\mathrm{H}^{+}$ions from exchangeable sites to form $\mathrm{H}_{2} \mathrm{O}$ and $\mathrm{CO}_{3}{ }^{2}$. The increase in soil pH resulting from the application of lime provides a more favorable environment for soil microbiological activity which increases the rate of release of plant nutrients, particularly N. Reduced acidity due to liming increased the availability of other plant nutrients mostly P (Dinkecha and Tsegaye 2017).

Similarly, Opala et al. (2018) reported an increase in soil pH (5.26) after the application of lime as compared to the control that had a pH value of 4.92 in acidic soils of Western Kenya. Correspondingly, Demissie et al. (2017) found increased soil pH after the application of lime, where it was changed from extremely acidic pH of 3.8 to medium and neutral pH of 6.63-6.86 in acid Soils of Wolmera district, West Showa Ethiopia. Likewise, Nadir (2005) reported the effect of lime in raising the soil $\mathrm{pH}$ and increase the availability of soil $\mathrm{P}$ by unlocking the soil fixed $\mathrm{P}$ into available $\mathrm{P}$ for crop use. Lime increases the availability of other nutrient elements mostly basic cations essential to crop use especially Ca which forms plant structure (Dinkecha and Tsegaye 2017).

The combined application of lime and inorganic fertilizer improved soil pH. The highest $\mathrm{pH}(6.85)$ was recorded from plots treated with $0.50 \mathrm{t}$ ha ${ }^{-1}$ lime mixed with $400 \mathrm{~kg} \mathrm{ha}^{-1}$ urea (Table 2). This is due to the dissociation of urea which releases $\mathrm{NH}_{4}{ }^{+}$, during plant up take of $\mathrm{NH}_{4}{ }^{+}$and the release of $\mathrm{HCO}_{3}{ }^{-}$that reacts with $\mathrm{H}^{+}$and form $\mathrm{H}_{2} \mathrm{CO}_{3}$ acid. This acid is a weak acid and dissociates into $\mathrm{H}_{2} \mathrm{O}$ and $\mathrm{CO}_{2}$. Eventually, $\mathrm{CO}_{2}$ is released to the atmosphere and water stays in the soil increasing $\mathrm{pH}$ by decreasing $\mathrm{H}^{+}$ion concentration in the soil solution. Similar increases in $\mathrm{pH}$ using integrated soil fertility management have been reported by Whalen et al. (2002); Moreira and Fageria (2010); Buni 2014). This might be due to the synergetic effect of lime integrated with $\mathrm{N}$ fertilizers.

\section{Change in soil organic carbon (OC)}

The maximum SOC content (2.51\%) was recorded in plots treated with $0.50 \mathrm{t} \mathrm{ha}^{-1}$ lime with $400 \mathrm{~kg} \mathrm{ha}^{-1}$ urea which was an increase by $52.60 \%$ from the initial soil OC analysis result (1.32\%). The minimum SOC (2.23\%) was recorded from plots treated with $0.50 \mathrm{t} \mathrm{ha}^{-1}$ lime and $100 \mathrm{~kg}$ ha-1 $\mathrm{N}(\mathrm{Table} 2)$. The increase in SOC could be associated with the decomposition of dead plant tissue like roots and leaves that contributed to plant biomass after the addition of lime. The increased microbial activities by liming are likely to increase SOC mineralization when the soils are cultivated and exposed to increased microbial activity Six et al.(2000).

Similarly, Aye et al.(2016) found that the higher OC of the soil after the application of lime integrated with NP fertilizers at Haryana Agricultural University, India. Besides, Antill (2001) also reported greater levels of SOC under integrated treatments of lime with inorganic fertilizer in acidic soil in the western Himalayas on maize crop. In a similar study, Moges (2018) reported increased amounts of OC from $2.23 \%$, to $2.49 \%$ after the application of lime with integrated inorganic fertilizers in the malt barley crop in Angolela Tera district Northwestern Ethiopia. However, the sole application of lime reduced SoC from

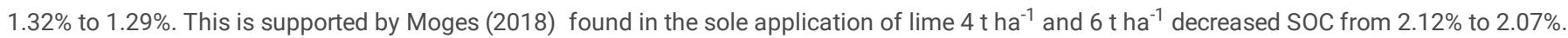

\section{Total Nitrogen content}

The maximum TN $(0.231 \%)$ was recorded in plots treated with $0.5 \mathrm{t} \mathrm{ha}^{-1}$ of lime and $400 \mathrm{~kg} \mathrm{ha}^{-1} \mathrm{~N}$. The lowest TN $(0.205 \%)$ was recorded in plots treated with $0.50 \mathrm{t} \mathrm{ha}^{-1}$ of lime and $100 \mathrm{~kg} \mathrm{ha}^{-1}$ urea (Table 2). Hence, it is clear that the application of lime with chemical fertilizers increased TN, which may be attributed to the mineralization of $\mathrm{N}$ from $\mathrm{OM}$ during the decomposition of organic matter. Generally, the combined application of lime and mineral fertilizers at different rates affected the contents of total $\mathrm{N}$ in the study area. Similarly, Kebede and Yamoah (2009) reported increased amount of TN in the vertisols of the Central Highlands of Ethiopia after the application of lime with mineral fertilizers. An increase in TN after the application of organic integrated with inorganic fertilizers has also been reported by Muhammad (2011); Agegnehu and Bekele (2005) in different part of Ethiopia.

\section{Change in available phosphorus}

In the sole application of inorganic fertilizer, the highest and lowest available P was 26.04 and $15.28 \mathrm{mg} \mathrm{kg}^{-1}$ recorded in treatments T5 and T2, respectively (Table 2). After the combined application of lime and urea, the maximum and the minimum values of available $\mathrm{P}$ were $30.43 \mathrm{mg} \mathrm{kg}{ }^{-1} \mathrm{and} 22.84 \mathrm{mg} \mathrm{kg}^{-1}$ in treatments $\mathrm{T} 10$ and T7, respectively.

Thus, the combined use of lime and chemical fertilizers increased available P content in the soil by mineralization or solubilizing of the native $\mathrm{P}$ reserves in soil Haynes and Naidu (1998). .As a result, soil available P after harvesting was much higher than the initial levels of lime-treated plots. Therefore, the major benefits of liming acid soils are the increased utilization of residual fertilizer phosphorus by maize crops. This might be due to the mineralization of OM and plant residues. The incorporation of lime has been shown to increase the amount of soluble organic matter which were mainly organic acids that increase the rate of desorption of phosphate and thus improves the available P content in the soil (Zsolnay and Gorlitz 1994). Similarly, Wanjiru (2018) showed an increase in soil available $\mathrm{P}$ after the application of lime, combined with manure and $\mathrm{P}$ fertilizer. Generally, the application of lime and mineral fertilizer increased P content. Similarly, Ghosh et al. (2019) reported that the combination of compost with chemical fertilizer helped in increasing the available P in the soil by mineralizing or solubilizing the native $\mathrm{P}$ reserves in Yilmana Desnsa district, Northwestern Ethiopia.

\section{Change in Cation exchange capacity}


After application of mineral fertilizer, the highest CEC was $23.36 \mathrm{cmolc} \mathrm{kg}^{-1}$ in T5 and the lowest $22.19 \mathrm{cmolc} \mathrm{kg}^{-1}$ in treatments T2 (Table 2). This might be due to increased $\mathrm{pH}$, so do the number of negative charges on soil colloids that increased the CEC. Similarly, Tesfaye (2017) found an increase in CEC value

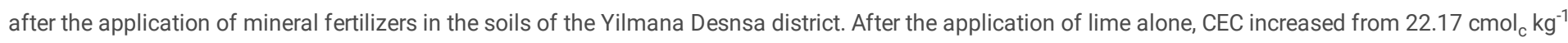
to $27.25 \mathrm{cmol}_{\mathrm{C}} \mathrm{kg}^{-1}$ in treatments $\mathrm{T} 1$ and T6. This increase in CEC could be linked to an increase in pH that increased the negative surface charges of soil colloids which subsequently increase the cation holding capacity of the soil. Similarly, Buni (2014) reported higher values of CEC after lime treatment was reported in Sodo Zuria district. Likewise, Yirga (2019) found the highest values of CEC in soils treated with the highest lime rate (3.75 $\mathrm{t}^{-1}$ ) in Welmera and Endibir district Southwestern Ethiopia. Besides, in the combined application of lime and $\mathrm{N}$ fertilizer, the highest and lowest CEC value was $35.38 \mathrm{cmolc} \mathrm{kg}^{-1}$ and $31.43 \mathrm{cmolc} \mathrm{kg}^{-1}$ recorded in treatments T10 and T7, respectively. This indicates that the combined application of lime and mineral fertilizer increased CEC to hold a higher amount of nutrients and that readily available to plants. The result was similar to Yirga (2019) who found higher CEC value due to integrated nutrient management.

\section{Effects in Grain Yield}

The economic analysis result indicates that, the maximum adjusted grain yield $\left(6,410.196 \mathrm{~kg} \mathrm{ha}^{-1}\right)$ was recorded from plot treated with $0.5 \mathrm{t}$ ha${ }^{1}$ ) lime with $300 \mathrm{~kg} \mathrm{ha}^{-1} \mathrm{~N}$ fertilizer while the min mum grain yield $\left(3,177.135 \mathrm{~kg} \mathrm{ha}^{-1}\right)$ was from the control (Table 4). The mariginal rate of return value is $805.24 \%$. This could be due to the improvement of soil physicohemical properties. Grain yield has posive correlat -0.543). This is in line with Opala et al. (2018) maximum maize yield $\left(2.35 \mathrm{t} \mathrm{ha}^{-1}\right)$ was obtained from application of $2.00 \mathrm{tha}{ }^{-1} \mathrm{CaCO}_{3}+26 \mathrm{~kg} \mathrm{P}+60 \mathrm{~kg}^{-1}$ $\mathrm{N}$ compared with the control (1.38 $\mathrm{t} \mathrm{ha}^{-1}$ ). Similarly Tolcha (2018) reported that $\mathrm{BH} 661$ maize yield potential varies between 9,500 and 12,000 $\mathrm{kg}^{-1}$ at research field and 6 and $8.50 \mathrm{t} \mathrm{ha}^{-1}$ at farmers' field under integrated agronomic managements.

\section{Conclusion And Recommendation}

Based on the result of this study we can conclude that; inherent physico-chemical properties of the soil changed either by sole or combined use of lime and $\mathrm{N}$ fertilizer. Soils with $0.5 \mathrm{t} \mathrm{ha}^{-1}$ lime and $300 \mathrm{~kg} \mathrm{ha}^{-1}$ nitrogen fertilizer was found in maximum net benefit. Thus, liming ahould be given more emphasis in acidic soil amelioration. Moreover, the government may facilitate the supply calcite $\left(\mathrm{CaCO}_{3}\right)$ and urea fertilizer to the farmers.

\section{Declarations}

\section{Acknowledgments}

The authors would like to thank Burie Polytechnic College. We thanked Bahir Dar University College of Agriculture and Environmental Sciences Department of Natural Resource Management. The authors would like to thank the editor and anonymous reviewers for their comments, which greatly improved the quality of this manuscript.

\section{Author Contributions}

This research article was contributed to by the authors in the following way: "Conceptualization and, methodology (Eyayu and Birtukan), conducting field experiment, formal analysis, investigation, data curation, writing original draft preparation, writing review and editing, B.H.T, K.B.T., F.B., and supervision, F.E.M and M.Y.G. All authors have read and agreed to the published version of the manuscript.

\section{Authors' information}

Birtukan Kebede is MSc in Watershed management, Soil and Water conservation from Bahir Dar University. She is a Trainer of Natural Resource Management in Burie Polytechnic College. She had working more than 6 years as Trainer.

Eyayu Molla is a Ph.D (Associate Professor) in soil biology working in the area of Soil biology. Recently he is a coordinator of Ph.D program in soil science besides of advising and guding MSc aswell as Ph.D students.

Yihenew G.Selassie is working in the area of Soil Science. Published more than 50 articles in the internationally peer reviewed journals. He is Professor (Soil Science), Executive Director for Research and Publication and Associate Editor, Journal of Agriculture and Environmental Sciences

Habtamu Belay is a Ph.D. candidate in Soil Science at Bahir Dar University and lecturer at department of Natural Resource Management in Debre Markos University. He has given different courses such as Introduction to Integrated Watershed Management, Land Use Planning, Soil and Water conservation, Introductory Soils, Land Degradation and Rehabilitation, Integrated soil fertility and plant nutrition and also published more than 4 articles in the internationally peer reviewed journals.

Tesfaye Bayu is a Ph.D. candidate in Soil Science at Bahir Dar University and lecturer at department of Natural Resource Management in Debre Markos University.

\section{Funding}

Not.

Data Availability Statement 
I declare that the data that support the findings of this study are openly available as requested by the authors.

\section{Ethics approval and consent to participate}

Not applicable to this manuscript submission.

\section{Consent for publication}

The manuscript does not contain any data or information from any person orindividual apart from their own field investigation. All data and information aregenerated and synthesized by the authors themselves.

\section{Competing interests}

The authors declare that they have no competing interests.

\section{Author detail}

${ }^{1}$ Department of Natural Resource and Plant Science, Burie Polytechnic College, Ethiopia, ${ }^{2}$ Department of Natural Resource Management, Bahir Dar University, Ethiopia , ${ }^{3}$ Department of Natural Resource Management, Debre Markos University, Ethiopia

\section{References}

Abera G, Wolde-Meskel E (2013) Soil properties, and soil organic carbon stocks of tropical andosol under different land uses.

Agegnehu G, Bekele T(2005) On-farm integrated soil fertility management in wheat on Nitisols of central Ethiopian highlands. Ethiopian Journal of Natural Resources;7(2):141-55.

Antil RS, Lovell RD, Hatch DJ, Jarvis SC (2001) Mineralization of nitrogen in permanent pastures amended with fertilizer or dung. Biology and fertility of soils;33(2):132-8.

Assefa D (2009) Assessment of upland erosion processes and farmer's perception of land conservation in Debre-Mewi watershed, near Lake Tana, Ethiopia. A Thesis Presented to the Faculty of Graduate School of Cornell University in Partial Fulfillment of the Requirements for the Degree of Masters of Professional Studies. 104p.

Aye NS, Sale PW, Tang C (2016) The impact of long-term liming on soil organic carbon and aggregate stability in low-input acid soils. Biology and Fertility of Soils,; 52(5), 697-709.

Bayu W, Rethman NFG, Hammes PS, Alemu G (2006) Application of farmyard manure improved the chemical and physical properties of the soil in a semi-arid area in Ethiopia. Biological agriculture \& horticulture, 24(3), 293-300.

Bello OB, Abdulmaliq SY, Afolabi MS, Ige SA (2010) Correlation and path coefficient analysis of yield and agronomic characters among open pollinated maize varieties and their $F 1$ hybrids in a diallel cross. African Journal of Biotechnology;9 (18):2633-9.

Blake GR (1965) Bulk density. Methods of Soil Analysis: Part 1 Physical and Mineralogical Properties, Including Statistics of Measurement and Sampling. 1965 Jan 1;9:374-90.

Brady NC, Weil RR, Weil RR (2008) The nature and properties of soils. Upper Saddle River, NJ: Prentice Hall.

Bremner JM, Mulvaney CS (1982) Nitrogen Total. p. 595-624. AL Page et al.(ed.) Methods of soil analysis. Part 2. Agron. Monogr. 9. ASA and SSSA, Madison, WI. Nitrogen Total. p. 595-624. In AL Page et al.(ed.) Methods of soil analysis. Part 2. 2nd ed. Agron. Monogr. 9. ASA and SSSA, Madison, WI.

Buni A (2014) Effects of liming acidic soils on improving soil properties and yield of haricot bean. J. Environ. Anal. Toxicol;5 (1):1-4.

Chapman HD (1965) Cation-exchange capacity. Methods of Soil Analysis: Part 2 Chemical and Microbiological Properties,1;9:891-901.

Demissie W, Kidanu S, Abera T, Cherukuri V (2017) Effects of lime, blended fertilizer (NPSB) and compost on yield and yield attributes of Barley (Hordium vulgare L.) on acid soils of Wolmera District, West Showa, Ethiopia. Ethiopian Journal of Applied Science and Technology;8(2):84-100.

Dinkecha K, Tsegaye D (2017) Effects of liming on physicochemical properties and nutrient availability of acidic soils in Welmera district, Central Highlands of Ethiopia. Biochemistry and Molecular Biology, 2(6), 102-109.

Ghosh D, Mandal M, Dey R, Kumar S (2019) Effect of integrated nutrient management on fertility status of soil in acid inceptisols. IJCS;7(6):1318-22.

Guo JH, Liu XJ, Zhang Y, Shen JL, Han WX, Zhang WF, Zhang FS (2010) Significant acidification in major Chinese croplands..Science; 327(5968), 1008-1010. Gupta PK (2000) Soil plant water and fertilizer analysis. Agrobios pub. Bikaner. India.

Haynes RJ, Naidu R (1998) Influence of lime, fertilizer and manure applications on soil organic matter content and soil physical conditions: a review. Nutrient cycling in agroecosystems, 51(2), 123-137. 
Karltun E, Mamo T, Bekele T, Gameda S, Kidanu S (2013) Ethiopian Soil Information System towards improved fertilizer recommendations in Ethiopia. Nutrient Indices for Categorization of Fertilizer Blends from EthioSIS District Soil Inventory Data Discussion Paper.

Kebede F, Yamoah C (2009) Soil fertility status and numass fertilizer recommendation of typic hapluusterts in the northern highlands of Ethiopia. World Applied Sciences Journal;6(11):1473-80.

Landon JR, Manual BT(1991) A handbook for soil survey and agricultural land evaluation in the tropics and subtropics. Hong Kong: Longman Scientific and Technical Group Ltd.

Mesfin S, Taye G, Hailemariam M (2009) Effects of integrated soil and water conservation measures on soil aggregate stability, soil organic matter and soil organic carbon stock of smallholder farmlands in semi-arid Northern Ethiopia. Carbon Management. 2018 Mar 4;9(2):155-64.

Moges T, Melese A, Tadesse G (2018) Effects of lime and phosphorus fertilizer levels on growth and yield components of malt barley (Hordeum distichum L.) in Angolelana Tera District, North Shewa Zone, Ethiopia. Adv Plants Agric Res; 8(6):582-9.

Moreira A, Fageria NK (2010) Liming influence on soil chemical properties, nutritional status and yield of alfalfa grown in acid soil. Revista Brasileira de Ciencia do solo. Aug;34(4):1231-9.

Muhammad W, Vaughan SM, Dalal RC Menzies NW (2011) Crop residues and fertilizer nitrogen influence residue decomposition and nitrous oxide emission from a Vertisol. Biology and Fertility of Soils, 47(1), 15-23.

Nadir WS, Othieno CO, Ng'etich WK, Ochuodho JO (2015) Evaluation of nitrogen fertilizer and lime on grain yield, protein content and kernel weight of barley (Hordeum vulgare L.) in Kenya. International Journal of Plant \& Soil Science:1-7.

Olsen SR (54) Estimation of available phosphorus in soils by extraction with sodium bicarbonate. US Department of Agriculture.

Onwonga RN, Lelei JJ, Mochoge BB (2010) Mineral nitrogen and microbial biomass dynamics under different acid soil management practices for maize production. Journal of Agricultural Science. ;2(1):16.

Opala PA, Odendo M, Muyekho FN (2018) Effects of lime and fertilizer on soil properties and maize yields in acid soils of Western Kenya. African Journal of Agricultural Research; 13(13), 657-663.

Shirani H, Hajabbasi MA, Afyuni M, Hemmat A (2002) Effects of farmyard manure and tillage systems on soil physical properties and corn yield in central Iran. Soil and tillage research;68(2), 101-108.

Six JA, Elliott ET, Paustian K (2000) Soil macroaggregate turnover and microaggregate formation: a mechanism for C sequestration under no-tillage agriculture. Soil Biology and Biochemistry,32(14), 2099-2103.

Tesfaye B (2017) Effect of Integrated Fertility Management on Soil Physicochemical Properties and Yield and Yield Components of Maize (Zea Mays L.) and Tef (Eragrostis Tef) at Yilmana Desnsa District, Northwestern Ethiopia (Doctoral dissertation, M. Sc. Thesis. Bahir Dar University. 116pp).

Tolcha T (2018) Soil Fertility Status and Response of Maize (Zea mays L.) to NPS and DAP Fertilizers Rates in Bako Tibe District, Western Ethiopia, MSc Thesis, Haramaya University.

Van Reeuwijk LP (1963) Procedure for soil analysis 4th ed. International soil reference center Wageningen.(ISRIC) technical paper.

Walkley A, Black IA (1994). An examination of the Degtjareff method for determining soil organic matter, and a proposed modification of the chromic acid titration method. Soil science;37(1):29-38.

WANJIRU KW (2018). LIME, MANURE AND INORGANIC FERTILIZER EFFECTS ON SOIL CHEMICAL PROPERTIES, MAIZE YIELD AND PROFITABILITY IN THARAKA-NITHI COUNTY, KENYA.

Whalen JK, Chang C, Clayton GW (2002) Cattle manure and lime amendments to improve crop production of acidic soils in northern Alberta. Canadian journal of soil science, 82(2), 227-238.

Worku M, Twumasi Afriyie S, Wolde L, Tadesse B, Demisie G, Bogale G, Wegary D, Prasanna BM (2011) Meeting the challenges of global climate change and food security through innovative maize research. Proceedings of the National Maize Workshop of Ethiopia, 3; Addis Ababa, Ethiopia; $18-20$ April, 2011.

CIMMYT; 2012 Mar 12.

Yihenew G. Selassie (2016) Response and economic feasibility of maize (Zea mays L.) to P fertilization in acidic Alfisols of North-western Ethiopia. Environ Syst Res (2016) 5:3,DOI 10.1186/s40068-016-0056-3

Yirga C, Erkossa T, Agegnehu G (2019) Soil Acidity Management.

Zsolnay A, Gorlitz H (1994) Water extractable organic matter in arable soils: effects of drought and long-term fertilization. Soil Biology and Biochemistry, 26(9), 1257-1261. 


\section{Figures}

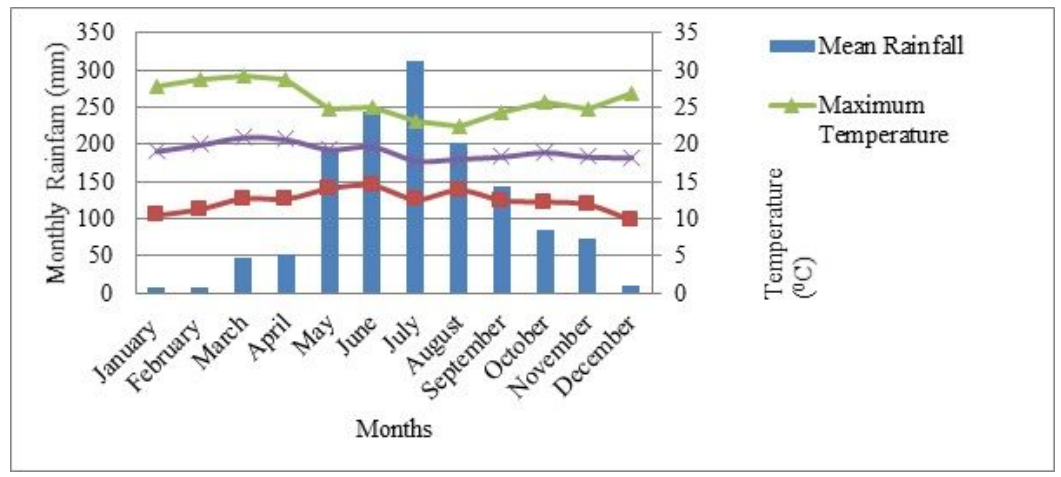

\section{Figure 1}

Monthly rainfall (mm), minimum, maximum and average air temperature (OC) of the study area during 2010-2019

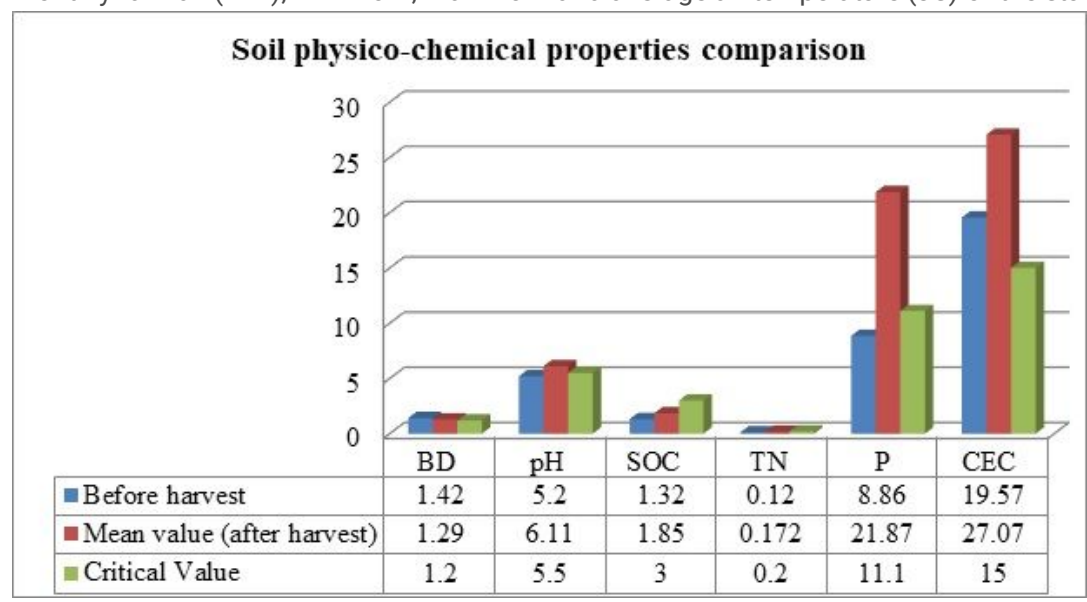

Figure 2

Plough depth $(0-20 \mathrm{~cm})$ soil physicochemical properties before and after harvest 